\title{
GNSS/CORS-Based Technology for Real-Time Monitoring of Landslides on Waste Dump - A Case Study at the Deo Nai South Dump, Vietnam
}

\author{
Cong Khai PHAM ${ }^{1, *)}$, Dinh Trong TRAN ${ }^{2, *)}$, Van Hai GGUYEN $^{3)}$
}

\footnotetext{
1) Hanoi University of Mining and Geology, 18 Vien street, Hanoi, Vietnam; email: phamcongkhai@humg.edu.vn

2) National University of Civil Engineering, 55 Giai Phong street, Hanoi, Vietnam; email: trongtd@nuce.edu.vn

3) ThuyLoi University - Second campus, Ho Chi Minh City, Vietnam; email: haingv@tlu.edu.vn
}

\section{http://doi.org/10.29227/IM-2020-02-23}

Submission date: 06-03-2020 | Review date: 22-09-2020

\section{Abstract}

Nowadays, there are many different methods for monitoring waste dump landslides based on GPS, total station, remote sensing, UAV, Lidar, etc. However, these technologies can only periodically monitor but cannot continuously monitor in real time. In recent years, GNSS CORS technology has been applied to continuously monitor real time waste dump landslides in open-pit mines to provide immediate or nearly-instant warning of waste dump landslides, which can timely prevent and minimize damages to property and human life. In the present work, the real time monitoring system of waste dump landslides monitoring based on GNSS CORS technology was designed and built. This real time monitoring system includes (1) the GNSS CORS station based on Leica technology, (2) the monitoring stations system, (3) the data collection, transmission and processing system based on Trimble technology and the warning system. This system allows continuous monitoring in real time and provides an instant warning if the landslide occurred. Moreover, it also has the advantage of being cheap, flexible and easy to install for monitoring stations. A simulation experiment results showed that our monitoring system operates stably and continuously $24 / 7$ with a horizontal accuracy of $\pm 3 \mathrm{~mm}$ and vertical accuracy of $\pm 5 \mathrm{~mm}$.

Keywords: GNSS CORS technology; continuously monitoring station system; landslide monitoring in real time; deo nai south waste dump

\section{Introduction}

Waste dump landslides are a type of hazard that often occurs in open-pit mines as a result of mining. The waste dump landslides often cause great damages to human life and property, destroy structures at the foot of the waste dump landslides and cause environmental degradation (Savvaidis., 2016; Zhiliu Wang et al., 2019).

Monitoring the landslides of waste dump surface will provide valuable information on landslides such as magnitude, velocity, and acceleration of landslides. This early detected information minimizes potential risks. One of the strategies to reduce the risks caused by landslides is a real-time monitoring and immediately warning system (Vu Van Khoa et al., 2018).

During recent years, the number and intensity of heavy rains have increased in Vietnam due to the impact of climate change. Therefore, the scale and frequency of risks caused by landslides of mountainous areas and waste dump in open-pit mines are increasing. In 1992, the catastrophic waste dump landslide disaster at the area mining manganese ore in Quang Trung commune - Tra Linh district - Cao Bang province killed 200 people. In 2004, a waste dump landslide of mining field 12 belonging to Lao Cai Apatite Company swept people and buried the equipment, killed 2 workers. A waste dump landslide in Cao Son coal mine buried many works and machines in 2006. In 2012, a waste rock landslide of Phan Me coal mine (belonging to Thai Nguyen Iron and Steel Joint Stock Company) buried the houses of 10 households living at the foot of the mountain (Luu Van Thuc et al., 2012).

According to information from the Viet Nam General Department of natural disaster prevention and control, there were 12 floods and rock landslides in 2018 causing 49 deaths,
14 missing people, 21 injuries, and damage nearly 1,000 billion VND. Currently, several large open-pit coal mines of Viet Nam Coal and Minerals Industry Group have lifted hundreds of millions of cubic meters of rock and soil into dumpsites. In addition, waste dumps with a height of hundreds of meters and the area of hundreds of land hectares have been formed at the mines. The large scale and long time exploitation have increased the height and area of landfills rapidly. When the height of the disposal site exceeds the allowed height according to the stable conditions of waste rock and soil, the surface of the waste dump will be eroded and drifted which causes environmental effects, production stoppages, damaging many properties and threatening human lives.

The waste dump is a terrain morphology created by man. The process of moving soil, surface deformation, and exogenous activities has been continuously occurred since dumping and lasted many years later (Lianhuan Wei et al., 2018). There are many methods to monitor rock landslides, from traditional geodetic methods on the ground using total stations and Global Navigation Satellite System (GNSS) (Malet et al., 2002; Volodymyr Nikulishyn et al., 2020) to the method of using remote sensing technology (Jaboyedoff et al., 2012; Tao Zhigang et al., 2018). The use of sensors attached to sliding blocks has also been studied (K. Georgieva et al., 2015). GPS (Global positioning system) has been applied to monitor landslides for settlements of hydroelectric power plant (Ruya Xiao et al., 2013), the results showed that the accuracy of monitoring horizontal and vertical displacements is $\pm 2 \mathrm{~mm}$ and $\pm 4 \mathrm{~mm}$, respectively. Different methods such as total stations (Serena Artese et al., 2018), ground laser scanners (Irwan Gumilar et al., 2017), GNSS technology, and remote sensing (Tommaso 


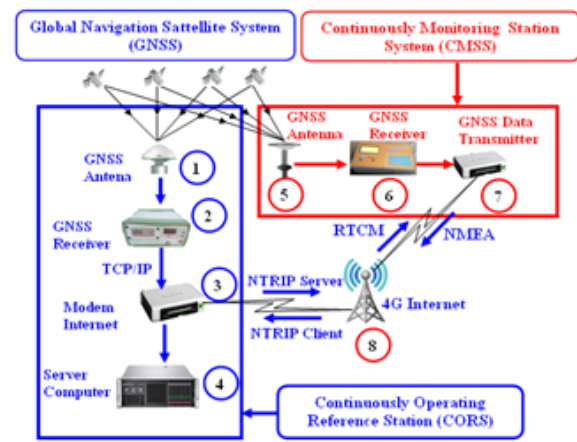

Fig. 1. Diagram of waste dump landslide monitoring system in real time

Rys. 1. Schemat systemu monitorowania osuwisk na zưałớikach w czasie rzeczywistym

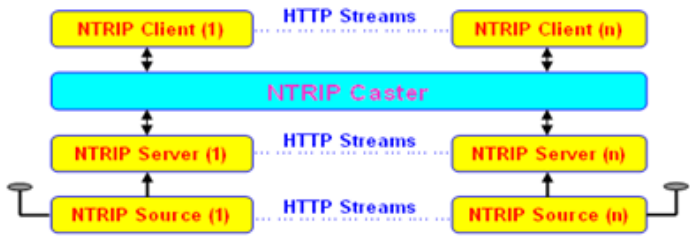

Fig. 2. Data transmission method of CORS station using NTRIP protocol

Rys. 2. Sposób transmisji danych stacji CORS z wykorzystaniem protokołu NTRIP

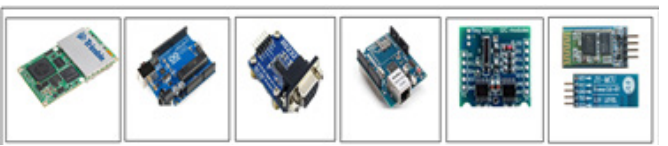

Fig. 3. Hardware for GNSS data acquisition and transmission device Rys. 3. Sprzęty do akwizycji i transmisji GNSS danych

Carla et al., 2019) have also been used for landslides monitoring.

Ground-based monitoring method is carried out in a 3-dimensional (3D) coordinate system with very high accuracy (up to millimetres). However, this method can monitors only for each local monitoring point but not the whole surface. On the contrary, the remote sensing method can monitor with a high density over the whole surface of the waste dump. However, disadvantages of this method are its low accuracy (only from a few $\mathrm{cms}$ to $\mathrm{dm}$ ), rarely provide 3D measurements except when using LiDAR images (Travelletti et al., 2014; Paolo Budetta et al. , 2020).

With the development of GNSS CORS (continuously operating reference station) technology, the monitoring landslides by multi-frequency receivers can be considered as the best solution due to its accuracy up to $\mathrm{mm}$ in the $3 \mathrm{D}$ coordinate system (Ustyna Adamczyk et al., 2013), continuous operation in all weather conditions. However, the price of multi-frequency receivers are still expensive (Malet et al., 2005), which significantly limits the number of monitoring points. In order to deploy dense monitoring points in the landslide area, the cost of the receiver must be reduced. In recent years, GNSS chips have been marketed at low cost by some manufacturers (Takasu et al., 2008), which has resulted in low price GNSS receivers. For low-cost landslide monitoring systems, GNSS satellite receivers should be small, compact, high accuracy, and low cost (K.S.C.Kuang et al., 2015). These GNSS chip and antenna are used to design and develop a landslide monitoring system that can be continuously monitored $24 / 7$ by using solar panels with a capacity of $30 \mathrm{~W}$ and batteries. The system is integrated with the data transmitter set via wifi modem and Dcom $4 \mathrm{G}$ to transmit monitoring data in real time.

In this work, we present the design and development of the waste dump landslides monitoring system in real time based on GNSS CORS technology. Firstly, the system of CORS stations with technology and equipment of Leica was designed and built-in terms of hardware and software. Then, the system of monitoring stations was designed, manufactured, and developed in both hardware and software. Simulation experiments using test equipment showed that the system stably and continuously operates and provides data and warn out landslides in real time.

\section{Method and technique for the continuous monitoring of waste dump landslides in real time}

2.1. General principle of continuous monitoring of waste dump landslide in real time

The monitoring of waste dump landslide is essentially the determination of the position change of môitorint points in the $3 \mathrm{D}$ coordinate system over a period of time. If the time interval between two monitoring epochs is long (in days, months, quarters), it is called cyclic monitoring. Otherwise, if the monitoring time is short (in seconds, minutes), it is called continuous monitoring.

The equation for calculating displacement and deformation of waste dump landslide is shown in the following formula (Hepi Hapsari Handayani et al., 2015):

$$
d p=R ' p-R p=d p(X p, Y p, H p, t)
$$


Tab. 1. Name of modules for GNSS data acquisition and transmission system

Tab. 1. Nazwa modułów systemu akwizycji i transmisji GNSS danych

\begin{tabular}{|c|l|}
\hline ID & \multicolumn{1}{|c|}{ Device name } \\
\hline a & BD970 Trimble module for GNSS receiving \\
\hline b & Arduino UNOR3 module for data processing \\
\hline c & Max232 signal acquisition module \\
\hline d & Shield W5100 module ethernet \\
\hline e & Real time module \\
\hline f & Bluetooth module \\
\hline
\end{tabular}

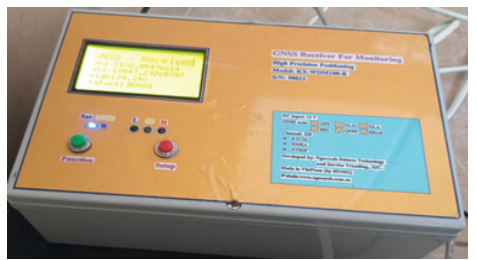

Fig. 4. GNSS data transmitter and Receiver Rys. 4. Nadajnik i odbiornik GNSS danych
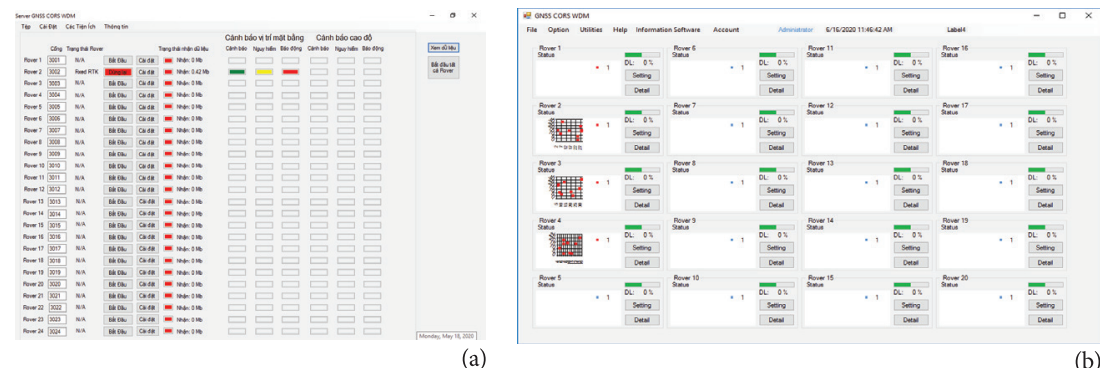

(a)

(b)

Fig. 5. User interface of Server GNSS CORS WDM Software (a) and GNSS CORS WDM Software (b)

Rys. 5. Interfejs użytkownika Oprogramowanie serwera GNSS CORS WD (a) Oprogramowanie GNSS CORS WDM (b)

where:

$\mathrm{Rp}$ - position of point $\mathrm{P}$ at the epoch $\mathrm{t}=0$ (before deformation);

R'p - position of point $\mathrm{P}$ at the epoch $\mathrm{t}>0$ (after deformation).

The deformation and displacement in formula (1) are defined in 4D, including 3D according to component coordinates $\mathrm{X}, \mathrm{Y}, \mathrm{H}$, and the 4 th $\mathrm{D}$ is epoch $\mathrm{t}$.

The displacement along each coordinate axes $\mathrm{X}, \mathrm{Y}$ is determined by the following formulas:

$$
\begin{aligned}
& D x=X_{i}(t+1)-X i(t) \\
& D y=Y_{i}(t+1)-Y i(t)
\end{aligned}
$$

Then, the horizontal displacement is calculed:

$$
D p=\sqrt{D x^{2}+D y^{2}}
$$

And the vertical displcement (settlement):

$$
\eta=H_{i}(t+1)-H_{i}(t)
$$

where:

$\mathrm{X}_{\mathrm{i}}(\mathrm{t}), \mathrm{Y}_{\mathrm{i}}(\mathrm{t}), \mathrm{H}_{\mathrm{i}}(\mathrm{t})$ are the coordinates of the ith point at epoch $\mathrm{t}$ (before deformation).

$X_{i}(t+1), Y_{i}(t+1), H_{i}(t+1)$ are the coordinates of the ith point at time $(t+1)$ (after the deformation).

Thus, the nature of the displacement monitoring of waste dump landslide is to determine the coordinates of the monitoring points at different times. Real time displacement mon- itoring is to continuously and instantaneously determine the coordinates of the monitoring points. This process is performed by a technical solution based on GNSS CORS technology.

\subsection{Designing a monitoring system of waste dump landslide in real time}

The landslide monitoring system for the waste dump in real time is designed based on the GNSS/CORS technology. The design system consists of two major parts. The first part is the CORS station, and the second part is the Continuously Monitoring Station System (CMSS) (Figure 1).

The installed CORS station system consists of two basic parts, such as hardware and software. Hardware includes GNSS antenna (1), GNSS Net S8+ receiver (2), modem and internet connection (3), and host computer (4). Softwares for controlling CORS stations include station management software (NRS-Station) and user management software (NRS-Server).

CMSS also includes hardware and software. The hardware consists of the GNSS antennas (5), GNSS data acquisition, and transmission equipment (6), Modem (7), and wireless internet connection (8). Our self-developed software includes 1) software to receive and transmit GNSS data from the monitoring station to CORS station (Server GNSS CORS WDM) and 2) software for processing monitored data to calculate the displacement of waste dump (GNSS CORS WDM).

The operating principle of the CMSS is based on the operation principle of the GNSS CORS system. The GNSS satellite signals are received by the antenna (1), transmitted to 


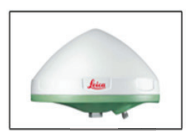

(a)

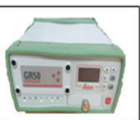

(b)

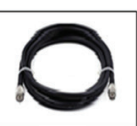

(c)

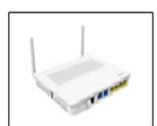

$(\mathrm{d}$

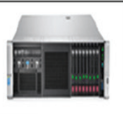

(e)

Fig. 6. Components of the CORS system based on Leica technology

Rys. 6. Elementy systemu CORS opartego na technologii Leica

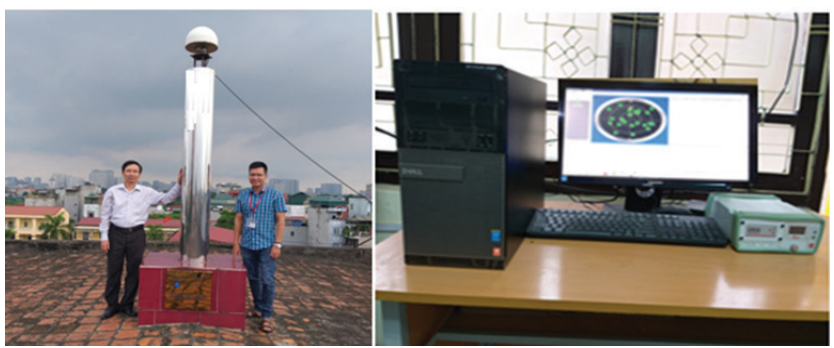

Fig. 7. Established CORS-N001system

Rys. 7. Założony system CORS-N001

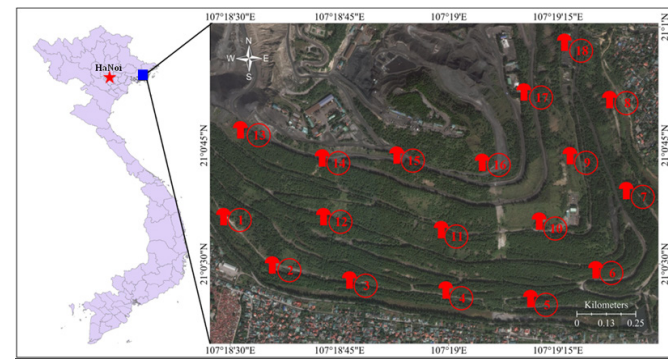

Fig. 8. Studied area and location of monitoring stations Rys. 8. Badany obszar i rozmieszczenie stacji monitorujących

the GNSS Net S8+ receiver via a dedicated cable, where the satellite signals are decoded and passed through the Modem (3) to the host computer (4). Through the host computer, which is connected to an internet connection with a static IP address, it is possible to decentralize management depending on each monitoring station with two accompanying software: NRS-Station that calculates data and distribution of GNSS observation data) and NRS-Server that provides differential corrections for monitoring stations, processes data and estimates ambiguities of monitoring stations, sets up processing options (including the tropospheric model, the ionospheric effect, and the satellite orbit). Data observation of CORS station is continuously collected every 1 second, 15 seconds, or 30 seconds depending on the requirements of displacement monitoring. This duration of observation is set up in NRS-Station software. The data is stored in a certain directory in the Server according to the format of the RINEX file.

The displacement monitoring of waste dump is implemented by the method of GNSS/CORS/RTK. The monitoring station is a multi-frequency GNSS receiver with a telephone 3G/4G SIM (Subscriber Identity Module) slot, connected to the CORS station and sends its approximate coordinates through a series of measurement data with NMEA's standard data format of the National Marine Electronics Association NMEA (Kai Shi et al., 2017).

The server NRS-Server software will calculate and determine the corrections for coordinates of the monitoring station and transmit in RTCM data format by the data transmission and acquisition equipment (GNSS Data Transmitter) that was researched, designed, and developed by ourselves.

The exact coordinates of the monitoring station are calculated using the formula (6):

$$
\left.\begin{array}{l}
\mathrm{X}_{\mathrm{M}}=\mathrm{X}_{\mathrm{M}}(\mathrm{t})+\delta \mathrm{x}(\mathrm{t}) \\
\mathrm{Y}_{\mathrm{M}}=\mathrm{Y}_{\mathrm{M}}(\mathrm{t})+\delta \mathrm{y}(\mathrm{t}) \\
\mathrm{Z}_{\mathrm{M}}=\mathrm{Z}_{\mathrm{M}}(\mathrm{t})+\delta \mathrm{z}(\mathrm{t})
\end{array}\right\}
$$

where:

$\mathrm{X}_{\mathrm{M}}, \mathrm{Y}_{\mathrm{M}}, \mathrm{Z}_{\mathrm{M}}$ are the exact coordinates;

$\mathrm{X}_{\mathrm{M}}(\mathrm{t}), \mathrm{Y}_{\mathrm{M}}(\mathrm{t}), \mathrm{Z}_{\mathrm{M}}(\mathrm{t})$ are measurement coordinates at epoch $\mathrm{t}$; $\delta \mathrm{x}(\mathrm{t}), \delta \mathrm{y}(\mathrm{t}), \delta \mathrm{z}(\mathrm{t})$ are the correction, calculated by formula (7):

$$
\begin{aligned}
& \delta \mathrm{x}(\mathrm{t})=\mathrm{X}_{\text {CORS }}-\mathrm{X}_{\text {CORS }}(\mathrm{t}) \\
& \delta \mathrm{y}(\mathrm{t})=\mathrm{Y}_{\text {CORS }}-\mathrm{Y}_{\text {CORS }}(\mathrm{t}) \\
& \delta \mathrm{z}(\mathrm{t})=\mathrm{Z}_{\text {CORS }}-\mathrm{Z}_{\text {CORS }}(\mathrm{t})
\end{aligned}
$$

where:

$\mathrm{X}_{\mathrm{CORS}}, \mathrm{Y}_{\mathrm{CORS}}, \mathrm{Z}_{\mathrm{CORS}}$ are known coordinates of CORS station; $\mathrm{X}_{\text {CORS }}(\mathrm{t}), \mathrm{Y}_{\text {CORS }}(\mathrm{t}), \mathrm{Z}_{\text {CORS }}(\mathrm{t})$ are measurement coordinates of CORS stations at epochs $t$.

The correcting data transmission and measurement reading messages in the NMEA format is implemented by NTRIP (Networked Transport of RTCM via Internet Protocol) protocol on the basis of IP (Internet Protocol) network. The data transmission method of CORS station network under the NTRIP protocol is shown in Figure 2.

NTRIP is an application that supports streaming GNSS data over the Internet. NTRIP is designed to streaming dif- 


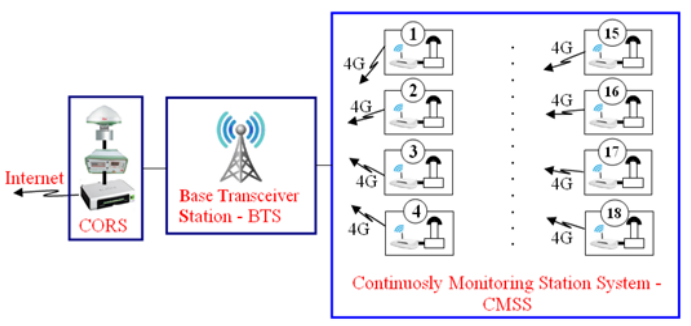

Fig. 9. Diagram design of data transmission network of monitoring system Rys. 9. Schemat budowy sieci transmisji danych systemu monitoringu

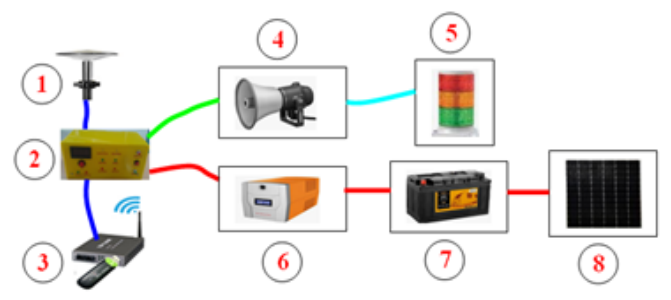

Fig. 10. Diagram of device connection at a monitoring station Rys. 10. Schemat podłączenia urządzenia na stacji monitorującej

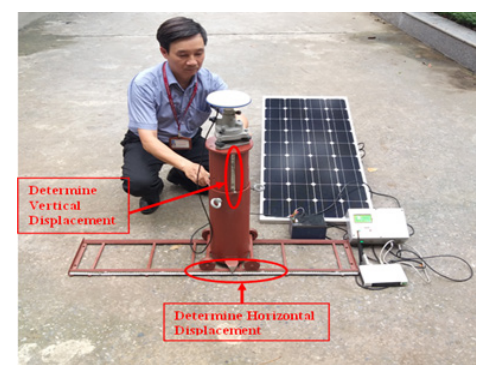

Fig. 11. Simulation experiment system the displacement in real time

Rys. 11. Symulacyjny system doświadczalny przemieszczenia w czasie rzeczywistym

ferential correction data or other GNSS data to monitoring stations over the wireless Internet access. NTRIP consists of three system software components: NtripClients, NtripServers, and NtripCasters.

The NtripCaster is the actual HTTP server program, while NtripClient and NtripServer act as HTTP clients.

\section{Design and development of GNSS data acquisition and transmission equipment}

\subsection{Design of hardware system}

Receiving and transmitting data from the monitoring station to CORS station is continuously carried out to provide the spatial position of the monitoring point in real time. The GNSS data acquisition and transmission equipment which includes the main modules, as shown in Figure 3 are designed and developed by ourselves.

\subsubsection{Module BD970}

The Trimble BD970 is a compact multi-constellation receiver designed to deliver centimetre accuracy to a variety of applications. The Trimble BD970 supports 220 channels of GNSS signals, including L2C/L5 of GPS, L1/L2 of GLONASS, B1/B2 of BeiDou, and L1 BOC/E5A/E5B of Galileo.

Network Protocols supported, including NTP Server, NTripCaster, TripServer, NTripClient. Baud rates up to
115,200. Inputs format CMR, CMR+, SCMRX, RTCM 2.1, $2.2,2.3,3.0,3.18$.

Its output format: NMEA-0183, GSV, AVR, RMC, HDT, VGK, VHD, ROT, GGK, GGA, GSA, ZDA, VTG, GST, PJT, PJK, BPQ, GLL, GRS, GBS.

BD970 has the horizontal accuracy of $\pm(0.008 \mathrm{~m}+1 \mathrm{ppm})$ and vertical accuracy of $\pm(0.015 \mathrm{~m}+1 \mathrm{ppm})$.

\subsubsection{Module for data processing Arduino UNO R3}

The data processing Arduino UNO R3 is a central control module that controls the operation of other modules, and codes are directly loaded on the ATmega 328 microprocessor. In signal transmission protocols, the ATmega328 is responsible for receiving data and returning them to other modules; from here, the data form continuous and interdependent connections.

This module is designed with seven analogue pins, 13 digital pins, and 6/13 integrated digital pins. Board runs in direct DC voltage range from $7 \mathrm{~V}$ to $20 \mathrm{~V}$, a new type of ATmega 328 chip, AVR family, operates 8 -bit platforms, $5 \mathrm{~V}$ voltage, $0.2 \mathrm{~mA}$ current, and all Boards have a level power consumption of $2.5 \mathrm{~W}$.

\subsubsection{Signal acquisition module Max232}

Max232 signal acquisition module is a device for transferring RS232 (Recommended Standard 232) signal into the 
Tab. 3. The NMEA data collected at the monitoring station on August 20th 2019

Tab. 3. Dane NMEA zebrane w stacji monitorującej 20 sierpnia 2019 roku

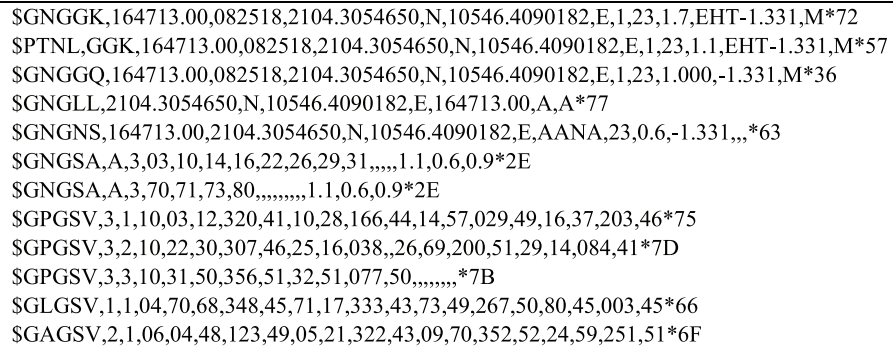

Tab. 4. GNGGA data according to NMEA 0183 format standard

Tab. 4. Dane GNGGA zgodnie ze standardem formatu NMEA 0183

\begin{tabular}{|c|}
\hline $95 * 4 \mathrm{C}$ \\
\hline$\$$ GNGGA, $070310.00,2104.30000020, \mathrm{~N}, 10546.41406564, \mathrm{E}, 4,22,0.7,23.699, \mathrm{M},-28.333, \mathrm{M}, 1.0,4095 * 41$ \\
\hline \$GNGGA,070311.00,2104.29999998,N,10546.41406593,E,4,22,0.7,23.703,M,-28.333,M,1.0,4095*41 \\
\hline \$GNGGA,070312.00,2104.29999893,N,10546.41406725,E,4,22,0.7,23.700,M,-28.333,M,1.0,4095*44 \\
\hline \$GNGGA,070313.00,2104.29999942,N,10546.41406699,E,4,22,0.7,23.701,M,-28.333,M,1.0,4095*4F \\
\hline \$GNGGA,070314.00,2104.29999894,N,10546.41406737,E,4,22,0.7,23.701,M,-28.333,M,1.0,4095*47 \\
\hline$\$$ GNGGA, $070315.00,2104.30000032, \mathrm{~N}, 10546.41406652, \mathrm{E}, 4,22,0.7,23.689, \mathrm{M},-28.333, \mathrm{M}, 1.0,4095 * 40$ \\
\hline \$GNGGA, $070316.00,2104.29999938, \mathrm{~N}, 10546.41406966, \mathrm{E}, 4,22,0.7,23.699, \mathrm{M},-28.333, \mathrm{M}, 1.0,4095 * 48$ \\
\hline \$GNGGA,070317.00,2104.29999921,N,10546.41406725,E,4,22,0.7,23.698,M,-28.333,M,1.0,4095*49 \\
\hline \$GNGGA,070318.00,2104.29999947,N,10546.41406839,E,4,22,0.7,23.701,M,-28.333,M,1.0,4095*45 \\
\hline \$GNGGA,070319.00,2104.29999955,N,10546.41406849,E,4,22,0.7,23.696,M,-28.333,M,1.0,4095*4F \\
\hline \$GNGGA,070320.00,2104.29999779,N,10546.41406726,E,4,22,0.7,23.699,M,-28.333,M,1.0,4095*4C \\
\hline
\end{tabular}

TTL (Transistor-Transistor Logic) signal, which is able to create communication between RS232 standard devices and TTL standard devices. Characteristics of the module are highly accurate, reliable in data preservation, with high processing speed, small power consumption, and signal delay.

\subsubsection{Ethernet W5100 module for data storage and data trans- mission to Server}

Ethernet W5100 module is a transmission system as well as a data storage system. Module integrated to Ethernet W5100 processor chip can give a LAN (Local Area Network) network transfer rate up to $100 \mathrm{Mbps}$. It is additionally integrated to Micro SD memory card in up to $4 \mathrm{~Gb}$ capacity.

The module also integrates status indicating lights including LAN, Full, RX, TX,... to make error control more flexible.

\subsubsection{Real time module}

Real time module supplies the real time for Arduino to determine the time that data is transferred from monitoring stations to CORS station. The real time module is periodically calibrated to the satellite time to always ensures the accuracy required. Real time module connects directly with Arduino using IC2s standard with analogue five or analogue six pins. The module is directly powered by $5 \mathrm{~V}$ from Board Arduino.

\subsubsection{Module Bluetooth}

Bluetooth module was used to control and easily communicate with a microcontroller via only two pins Tx and Rx.

The device for communicating with the Bluetooth module is the Arduino UNO R3 module via the Serial port. To control the Bluetooth module, a computer program has been written in the $\mathrm{C} \#$ programming language, then uploaded to the GNSS receiver via USB through the Arduino programming tool.

All the above modules are integrated to create a GNSS data acquisition and transmission unit from the monitoring station to the CORS station management server. This device is called GNSS Data Transmitter and Receiver (Figure 4).

\subsection{Programming the system control software}

After a GNSS data acquisition and transmission, devices have been designed and installed, controlling software has been designed and programmed. They are written in NMEA's standard data format using the Arduino programming tool and the C\# programming language.

When software source code has been written and checked for errors, it is loaded into the GNSS data transmitter via the USB connector to the computer by Arduino's programming tool. The software controlling GNSS data acquisition and transmission functions follow:

- The satellite signal collected from monitoring stations in NMEA format is directly transmitted to Arduino via RS232 port;

The received Arduino signals are divided into two types \$GPGGA, \$GNGGA, and other NMEA signals;

- The \$GNGGA signals are transmitted to the Server according to NTRIP server protocol, and other NMEA signals are simultaneously transmitted to Ethernet W5100 and stored in the Micro SD memory card that is integrated into Ethernet W5100 in the text file format;

\$GNGGA signals are processed, and the results are sent to the software in the Server to provide instant location;

These data are automatically processed by our self-developed software (GNSS CORS WDM), and waste dump displacement is determined with the highest accuracy.

\subsection{Programming software to receive and process monitoring data of waste dump landslide \\ Waste dump landslide monitoring data are continuously transmitted from the monitoring station to the host computer}


Tab. 5. Comparison of horizontal and vertical displacement testing

Tab. 5. Porównanie przemieszczeń poziomych i pionowych

\begin{tabular}{|c|c|c|c|c|c|c|}
\hline \multirow[b]{2}{*}{$\begin{array}{l}\text { Experiment } \\
\text { times }\end{array}$} & \multicolumn{3}{|c|}{ Horizontal displacement (mm) } & \multicolumn{3}{|c|}{ Vertical displacement (mm) } \\
\hline & $\begin{array}{c}\text { Measured } \\
\text { by a steel } \\
\text { ruler }\end{array}$ & $\begin{array}{c}\text { Observed } \\
\text { by Net S8+ } \\
\text { CMSS }\end{array}$ & $\Delta \mathrm{D}$ & $\begin{array}{c}\text { Measured } \\
\text { by a steel } \\
\text { ruler }\end{array}$ & $\begin{array}{l}\text { Observed } \\
\text { by CMSS } \\
\text { equipment }\end{array}$ & $\Delta \mathbf{H}$ \\
\hline August $20^{\text {th }}$ & 36 & 38.5 & 2.5 & 45 & 49.5 & 4.5 \\
\hline August $22^{\text {nd }}$ & 45 & 47.0 & 2.0 & 50 & 54.0 & 4.0 \\
\hline August $24^{\text {th }}$ & 55 & 57.1 & 2.1 & 55 & 59.5 & 4.5 \\
\hline August $26^{\text {th }}$ & 65 & 62.8 & 2.2 & 60 & 63.9 & 3.9 \\
\hline
\end{tabular}

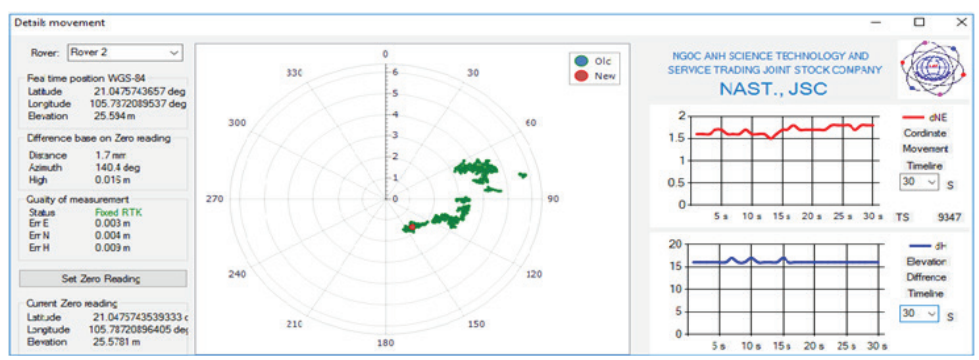

Fig. 12. Displacement rate over time

Rys. 12. Szybkość przemieszczania w czasie

(Server) through the data transmission unit.

There is two software designed to ensure that the monitoring station system can continuously work without being conflicted with data. The first software is called Server GNSS CORS WDM has the function of receiving data from the rovers at the monitoring point and sending them to the Server (Pham Cong Khai et al., 2019). The second software is called GNSS CORS WDM has the function of analyzing and processing data received from the first software to get the most accurate result file and to identify and display the deformation and displacement quantities.

The software for analyzing and processing deformation and displacement monitoring data of construction works is written in VB.Net programming language by Visual Studio 2017 programming tool. The interface of the software can be seen in Figure 5.

The main modules of the software include:

- Module for system control of data acquisition and transmission;

- Module for data management;

- Module for processing real time GNSS data;

- Module for processing timeline data;

- Composite modules for determining vertical and horizontal displacements;

- Modules for warning bypass signal light and alarm.

\subsection{Establishment of continuously operating reference sta- tion}

CORS system was set up by Leica technology, including some main components such as GNSS antenna, GNSS GR50 receiver, data transmission cable, wifi modem, Server, and some other devices (Figure 6).

\subsubsection{GNSS CORS Antenna}

The AR25 antenna is used for CORS station to receive GNSS signal. It was manufactured by Leica and designed in the style of choke ring antenna, used less elastic material, and could eliminate miscellaneous waves due to multi-path effects. The antenna is designed to be centred in 4 points; the stability of the device centre reaches $0.8 \mathrm{~mm}$, the accuracy of the antenna phase centre is $2 \mathrm{~mm}$. This antenna is capable of observing GNSS satellites with the smallest elevation mask (Figure 6a). The antenna can receive satellite signals of GPS, GLONASS, Galileo, Beidou, and QZSS.

\subsubsection{GNSS CORS Receiver}

The GNSS CORS receiver (Figure 6b) used for the CORS station is the GRICA of Leica, capable of receiving 220 channels, supporting GPS, GLONASS, Galileo, Beidou and QZSS systems; supporting to export international calibration numbers RTCM 2.1, RTCM 2.2, RTCM 2.3, RTCM 3.0, and RTCM 3.1, directly supporting NTRIP standard; supporting remote control of configuration establishment. Its connection ports include Serial, USB, Bluetooth, Ethernet with capabilities HTTP, HTTPS, TCP / IP, FTP, NTRIP Caster, NTRIP Server, NTRIP Client, and Proxy Server.

The horizontal and vertical accuracy of GRICA is $\pm(3 \mathrm{~mm}$ $+0.1 \mathrm{ppm})$ and $\pm(4 \mathrm{~mm}+0.4 \mathrm{ppm})$, respectively.

Data file standards: RINEX v2.11 and RINEX v3.0.

\subsubsection{GNSS Antenna cable}

The antenna cable is responsible for transmitting satellite signals from the antenna to the CORS receiver. The used antenna cable is high-quality LMR400 (Figure 6c), resistant to noise, waterproof, small-signal loss, and has a long service life.

\subsubsection{Router and Modem}

Router and Modem are used for internet connection of the entire CORS system (Figure 6d), they are responsible for transmitting the calibration data from the IGS (International GNSS Service) network to the CORS stations, transmitting the correction data from the CORS to the monitoring stations, receiving measured data from môitoring stations and transferring measured data from CORS station to IGS network in order to continue calculating instant coordinates for CORS.

The Internet should be highly stable, uninterrupted during working. Two ports 6060 and 8080 are installed at the 
Router to be able to access data with the default static IP on the Server as 118.70.171.179.

\subsubsection{Server computer}

The server computer used for establishing HP's CORS (Figure 6e) has a high configuration with $32 \mathrm{~Gb}$ RAM and three hard drives, $500 \mathrm{~Gb}$ capacity for each drive. The Server has a UPS (uninterruptible power ) system to ensure the Server does not suddenly be power-off.

The host computer is installed with Spider software to calculate data, allocate static receiving station data, provide differential information for monitoring stations, process data of monitoring station network, and adjust the multi-value integers of the whole network, and set up a calibration model (including the correction of the troposphere, ionosphere, satellite orbits).

CORS system is set up and installed completely in Hanoi university of mining and geology (Vietnam), called CORS-N001, as shown in Figure 7.

\section{Design of landslide monitoring system for Deo Nai South waste dump, Vietnam}

\subsection{Introduction to Deo Nai South waste dump}

Deo Nai South waste dump is located in Cam Pha City, Quang Ninh Province, Vietnam, limited by the coordinates of $21000^{\prime} 15^{\prime \prime} \mathrm{N}$ to $21001^{\prime} 00^{\prime \prime} \mathrm{N}$ and $107 \mathrm{o} 18^{\prime} 30^{\prime \prime} \mathrm{E}$ to $107 \mathrm{o} 19^{\prime} 30^{\prime \prime} \mathrm{E}$ (Figure 8).

Deo Nai South waste dump is the area containing rock and soil waste of two coal mines Deo Nai and Coc Sau. After many years of existence, the amount of soil and stone dumped into this waste dump is up to hundreds of millions of cubic meters, the surface area, height, and of length the waste dump is about 225 hectares, $250 \mathrm{~m}$, and over $3 \mathrm{~km}$, respectively. The waste dump is located in the north of residential area of Cam Pha city, Quang Ninh province, Vietnam. Since 2004 Nam Deo Nai waste dump has been renovated and cut into 8 layers with the height of each floor from 20 to 35 meters, the surface width of each floor is from 30 to 50 meters, the overall slope of the waste dump slope is from 24 to 26 degrees.

Deo Nai South waste dump is at high risk of landslides, especially in the rainy season. Moreover, at the foot of DeoNai, many households live.

Therefore, it is necessary to establish a real time continuous monitoring system for Deo Nai waste dump landslide, in order to provide data for landslide forecasts, in order to timely alert landslide phenomena.

\subsection{Design of data transmission network for monitoring sys- tem}

Data transmission of a monitoring system based on GNSS CORS technology is usually conducted via NTRIP protocol. Data is transmitted via the Internet or $4 \mathrm{G}$ telecommunication. Data transmission via $4 \mathrm{G}$ telecommunication network is more convenient because it is not necessary to build internet infrastructure. The diagram of designing data transmission of monitoring stations is shown in Figure 9.

\subsection{Design of equipment connection at a monitoring station}

The components at the monitoring station must be connected to ensure the continuous reception of monitoring data with a frequency of at least one second receiving measurement information which is then processed and given instant warning by sound and images (warning lights) to identify the status and level of landslides.

The system of equipment and connection diagram at a monitoring station is designed as in Figure 10.

Equipment system of a monitoring station includes: Antenna for receiving GNSS satellite signal (1), GNSS receiver (2), Wifi Modem with 4G Dcom (3), Alarm Module (4), Warning Module (5), Power Control Module (6), UPS 12v (7), and Solar panels (8)

Among devices at the monitoring station, the GNSS receiver (2) has been investigated and developed by ourselves. This device can receive signals of all satellite systems such as GPS, GLONASS, Galileo, and Beidou with 220 channels.

\section{Simulation experiment and Results}

\subsection{Design, build equipment system to test the accuracy of waste dump landslide monitoring in real time}

For testing the operability, as well as the accuracy of Deo Nai waste dump landslide monitoring system. We manufacture the device to install the antenna of the monitoring station, which can accurately adjust the movement of the antenna.

This displacement test model (DTM) includes a horizontal rail attached with a horizontal steel ruler and a vertical steel ruler to determine horizontal and vertical displacement (Figure 11).

The GNSS Net S8+ (South Surveying \& Mapping Technology CO., LTD) receiver is installed to the DTM, and connected with other devices of the monitoring system such as GNSS data acquisition and transmission equipment, wireless internet modem, battery, solar battery. The GNSS receiver will automatically receive and transmit data to the Server. The indication lights will show the operating status of the monitoring station system (Figure 11).

\subsection{Testing and Processing monitored data}

Experiments for real time monitoring the displacement of DTM were performed in 4 days on August 20th, 22nd, 24th, and 26th, 2019.

During the experimental period, the Net S8+ was turned on to continuously receive GNSS signals and connect to the CORS-001 station. At the same time, the DTM was moved over a certain distance on which these distances are determined based on the steel ruler. These distances are used to compare the displacement calculated from the measured coordinates.

NMEA data collected by Net S8+ is continuously sent to the Server with a frequency of 10 messages per second. Table 3 shows a segment of the NMEA data file starting at 16:47:13, August 20th, 2019.

GPGGA and GPGST messages are filtered from NMEA data file to get the best positions. The analyzing process is carried out in the following three steps:

Firstly, check the integrity of the messages in the NMEA data file. It is necessary to check the integrity of the messages in this data file if the messages do not have enough information, do not use them. The integrity check of data is done by analyzing all characters in the range from $\$$ to ${ }^{*}$ of the NMEA message. 
Secondly, filter the messages coordinates on which they are fixed.

Thirdly, choose messages from step 2 but having the smallest positional uncertainties. Filtering out coordinates with positional uncertainties is done by analyzing the GPGST or GNGST message sequence.

The average coordinate is calculated from those that have been filtered out over a monitoring period. Then the displacement of the DTM between the two epochs is calculated by formulas (3), (4), (5), and (6).

In the GNGGA or GPGGA message sequence, if after the letter "E" there is number 4 , these messages are good. If there is the number $0,1,2,3$, or 5 , these are not taken. Table 4 shows a filtered message segment as an example.

For example with testing data on August 20th 2019, the displacement is determined as follows:

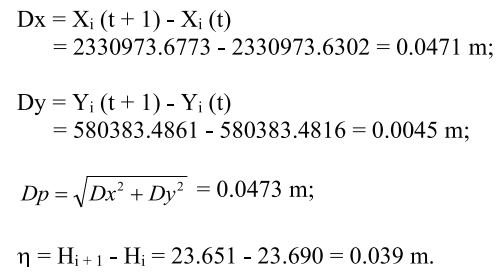

Table 5 shows the horizontal and vertical displacementdetermined by Net S8+ CMSS and directly measured by a steel ruler mounted on DTM. The difference of horizontal displacement $\Delta \mathrm{D}(\max 2.5 \mathrm{~mm}, \min 2.0 \mathrm{~mm})$ and the different vertical displacement $\Delta \mathrm{h}(\max 4.5 \mathrm{~mm}$, $\min 3.9 \mathrm{~mm})$ are very small compared to the accuracy requirement of the displacement of waste dump landslide.

The monitoring data shown in Table 1 were filtered out to get the calibrated coordinate values from the CORS station. The coordinates in the WGS84 coordinate system was transformed to VN 2000 coordinates using the formula (8).

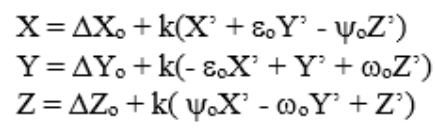

where:

$\mathrm{X}, \mathrm{Y}, \mathrm{Z}$ are the coordinates in the $\mathrm{VN}-2000$ system; $X^{\prime}, Y^{\prime}, Z^{\prime}$ are the coordinates in the WGS84 system; and 7 parameters of Helmert transformation, include: $\mathrm{k}$ is scale factor;

$\Delta \mathrm{X}_{\mathrm{o}}, \Delta \mathrm{Y}_{\mathrm{o}}, \Delta \mathrm{Z}_{\mathrm{o}}$ are the coordinate origin displacement param- eters;

Фo, $\psi \mathrm{o}, \Delta \mathrm{o}$ are three rotation angles of axes corresponding to $\mathrm{X}, \mathrm{Y}, \mathrm{Z}$.

The seven parameters of Helmert transformation from WGS84 to VN2000 coordinate system are published by the Ministry of Natural Resources and Environment, Vietnam.

\section{Conclusion}

The positioning on the ground is performed by setting up CORS using GNSS technology, the real time kinematic measurement technique with high accuracy is effectively applied in monitoring rock landslides in real time.

This work has focused on solving the problem of continuous monitoring of waste dump landslide using GNSS/CORS technology. A diagram of CMSS has been set up including CORS station system and monitoring stations. The message types of the GNSS data have been successfully studied and decoded, including NMEA format messages sent from the host monitoring station to Server of the CORS station.

A GNSS data transmission system has been designed to develop both hardware and software that can real time, continuously, and automatically monitor the waste dump landslide. The developed system automatically works well, stably, ensure, and instantaneously transmission of data from the monitoring station to the host computer.

In order to monitor the landslide of DeoNai South waste dump, a system including one CORS and CMSS of 18 monitoring stations has been designed. This system continuously $24 / 7$ operates and can instantly warn via alarms and signals.

GNSS data processing software designed and developed allows to process data and immediately determine the landslide process. The system of monitoring stations has been studied, developed, and tested by specialized equipment, showing that the monitoring system works well, stably, continuously, and ensures the required accuracy to monitor the displacement up to $\pm 3 \mathrm{~mm}$ in horizontal component and $\pm 5 \mathrm{~mm}$ in the vertical component.

\section{Acknowledgements:}

This research was financially supported by the Hanoi Department of Science and Technology (Project 01C-04/082016-3) and Ministry of Education and Training of Vietnam (project B2020-XDA-05). 


\section{Literature - References}

1. Tao Zhigang, Zhu Chun, Wang Yong, Wang Jiamin, He Manchao, and Zhang Bo (2018). Research on Stability of an Open-Pit Mine Dump with Fiber Optic Monitoring. Open Access Volume 2018, Article ID 9631706, 20 pages

2. Hepi Hapsari Handayani, Yuwono, Taufik M, 2015. Preliminary study of bridge deformation monitoring using GPS and CRP (case study: Suramadu Bridge). Procedia Environmental Sciences, 24, 266-276.

3. Lianhuan Wei, Yun Zhang, Zhanguo Zhao, Xiaoyu Zhong, Shanjun Liu, Yachun Mao and Jiayu Li, 2018. Analysis of Mining Waste Dump Site Stability Based on Multiple Remote Sensing Technologies. Remote Sensing, doi:10.3390/ rs10122025.

4. Ustyna Adamczyk, Marek caŁa, Jerzy flisiak, Malwina Kolano, MichaŁ Kowalski (2013). Slope stability analysis of waste dump in sandstone open pit Osielec. Studia Geotechnica et Mechanica, Vol. XXXV, No. 1, 2013

5. Zhiliu Wang, Bo Liu, Yanhui Han, Jian Wang, Biao Yao, Peng Zhang, 2019. Stability of inner dump slope and analytical solution based on circular failure: Illustrated with a case study. Computers and Geotechnics, Volume 117, 103241

6. Paolo Budetta, Michele Nappi, Sergio Santoro, Giuseppe Scalese, 2020. DinSAR monitoring of the landslide activity affecting a stretch of motorway in the Campania region of Southern Italy. Transportation Research Procedia 45, 285-292

7. Volodymyr Nikulishyn, Ihor Savchyn, Olexandr Lompas, Viktor Lozynskyi, 2020. Applying of geodetic methods for monitoring the effects of waste-slide at Lviv municipal solid waste landfill. Environmental Nanotechnology, Monitoring \& Management 13, 100291.

8. Kai Shi, Ming Xu, Haoxia Jin, Tong Qiao, XueYang, Ning Zheng, JianXu, Kim-Kwang Raymond Choo, 2017. A novel file carving algorithm for National Marine Electronics Association (NMEA) logs in GPS forensics. Digital Investigation, Volume 23, pp 11-21.

9. Malet J-P, Maquaire O, Calais E, 2002. The use of Global Positioning System for the continuous monitoring of landslides. Application to the Super-Sauze earthflow (Alpes de-Haute-Provence, France). Geomorphology 43, 33-54.

10. Malet, J.-P., van Asch, Th.W.J., Van Beek, R., Maquaire, O., 2005. Forecasting the behaviour of complex landslides with a spatially distributed hydrological model. Nat. Hazards, Earth Syst. Sci. 5, 71-85.

11. Jaboyedoff M, Oppikofer, T., Abellan, A., Derron, M.H., Loye, A., Metzger, R., Pedrazzini, A., 2012. Use of LiDAR in landslide investigation/a review. Nat. Hazards 61 (1), 5-28.

12. Travelletti J, Malet J-P, Delacourt C, 2014. Image-based correlation of laser scanning point cloud time series for landslide monitoring. Int. J. Appl. Earth Obs. Geoinf. 32, 1-18.

13. L. Benoit, P. Briole, O.Martin, C. Thom, J.-P. Malet, P. Ulrich., 2015. Monitoring landslide displacements with the Geocube wireless network of low-cost GPS. Engineering Geology 195, 111-121.

14. Takasu, T., Yasuda, A., 2008. Evaluation of RTK-GPS performance with low-cost single-frequency GPS receivers. International Symposium on GPS/GNSS 2008.

15. Luu Van Thuc, Đo Ngoc Tuoc, Le Xuan Thu, 2014. Causes deformation of waste dump in open pit mine and recommend some solutions to ensure stability. Results of research and development of mining science and technology. Institute Of Mining Science And Technology, VietNam.

16. Savvaidis, 2016. Existing Landslide Monitoring Systems and Techniques. Journal of Measurement, pages 242-258.

17. Vu Van Khoa, Shigeru Takayama, 2018. Wireless sensor network in landslide monitoring system with remote data management. Journal of Measurement, pages 214-229.

18. K. Georgieva, K. Smarsly, M. König and K. H. Law, 2015. An Autonomous Landslide Monitoring System Based on Wireless Sensor Networks. https://www.researchgate.net/publication/268438328.

19. K. S. C. Kuang, Qinghao Cao, 2015. A Low-Cost, Wireless Chemiluminescence-Based Deformation Sensor for Soil Movement and Landslide Monitoring.

20. Ruya Xiao, Xiufeng He, 2013. Real time landslide monitoring of Pubugou hydropower resettlement zone using continuous GPS. ttps://www.researchgate.net/publication/257633559.

21. Serena Artese, Michele Perrelli, 2018. Monitoring a Landslide with High Accuracy by Total Station: A DTM-Based Model to Correct for the Atmospheric Effects. www.mdpi.com/journal/geosciences.

22. Irwan Gumilar, Alif Fattah, Hasanuddin Z. Abidin, Vera Sadarviana, Nabila S. E. Putri, and Kristianto, 2017. Landslide monitoring using terrestrial laser scanner and robotic total station in Rancabali, West Java (Indonesia).

23. Tommaso Carlàa, Veronica Tofania, Luca Lombardia, Federico Raspinia, Silvia Bianchinia, Davide Bertolob, Patrick Thuegazb, Nicola Casagli, 2019. Combination of GNSS, satellite InSAR, and GBInSAR remote sensing monitoring to improve the understanding of a large landslide in high alpine environment. Geomorphology, pages 62-75. 
24. Pham Cong Khai, Le Van Canh, Nguyen Quoc Long, Nguyen Viet Nghia, Pham Van Chung, Vo Ngoc Dung, Nguyen Gia Trong, Le Duc Tinh, Nguyen Viet Ha, Nguyen Van Sang, 2019. Research on technology application continous monitoring of displacement and deformation of works in area of Hanoi City. Final report of Science and Technology project of city level. Grant number 01C-04/08-2016-3. Hanoi Department of Science and Technology.

25. Networked Transport of RTCM via Internet Protocol (Ntrip), Version 1.0. In: GDC (GNSS Data Center) [online]. Bundesamt für Kartographie und Geodäsie (BKG), 2004. [cit.26.05.2016]. Available from: http://igs.bkg.bund.de/ root_ftp/NTRIP/documentation/ NtripDocumentation.pdf/.

\section{WMonitorowanie osuwisk na zwałowiskach $w$ czasie rzeczywistym $w$ oparciu o technologie GNSS/CORS -studium przypadku na zwałowisku Deo Nai Południa, Vietnam}

Częste występujące ulewy maja katastrofalne skutki powodując osuwanie mas skalnych na zwałowisku. W wyniku tego następuje zniszczenie, zasypanie udządzeń, dróg dojazdowych itp. Obecnie istnieje wiele różnych metod monitorowania osuwisk nazwałowiskach w oparciu o GPS, tachimetr, teledetekcję, UAV, Lidar itp. Jednak technologie te moga monitorować tylko okresowo, nie moga monitorować w sposób ciagły w czasie rzeczywistym. W ostatnich latach, technologia GNSS CORS była stosowana do ciagłego monitorowania $w$ czasie rzeczywistym osuwisk na zwałowiskach w kopalniach odkrywkowych, aby zapewnić ostrzeżenie natychmiastowe lub prawie natychmiastowe o osuwiskach, co może na czas zapobiec i zminimalizować szkody mienia $i \dot{z} y c i a ~ l u d z i . ~ W$ artykule, przedstawiono system monitoringu osuwisk $w$ czasie rzeczywistym $w$ oparciu o technologię GNSS/CORS. Ten system monitoringu $w$ czasie rzeczywistym obejmuje (1) stacje GNSS CORS oparta na technologii Leica, (2) system stacji monitorujacych, (3) system zbierania, transmisji i przetwarzania danych oparty na technologii Trimble oraz system ostrzegawczy. System ten umożliwia ciagłe monitorowanie $w$ czasie rzeczywistym $i$ zapewnia natychmiastowe ostrzeżenie $w$ przypadku wystapienia osuwisk. Ponadto ma te zaletę, że jest tani, elastyczny $i$ łatwy $w$ instalacji dla stacji monitorujących. Wyniki eksperymentu symulacyjnego wykazały, że nasz system monitorowania działa stabilnie i nieprzerwanie 24 godziny na dobę, 7 dni w tygodniu $z$ dokładnościa pozioma $\pm 3 \mathrm{~mm} i$ dokładnością pionowa $\pm 5 \mathrm{~mm}$.

Słowa kluczowe: Technologia GNSS CORS; System Stacji Ciagłego Monitorowania; Monitorowanie osuwisk w czasie rzeczywistym; Wysypisko śmieci w Deo Nai South 